\title{
Citral Protects Human Endothelial Cells Against Hydrogen Peroxide-induced Oxidative Stress
}

\section{Sitral, İnsan Endotel Hücrelerini Hidrojen Peroksitin Neden Olduğu Oksidatif Strese Karşı Korur}

\author{
(D) Leila SAFAEIAN ${ }^{1 *}$, (D) Seyed Ebrahim SAJJADI2, (D) Hossein MONTAZERI ${ }^{1}$, (D) Farzaneh OHADI ${ }^{3}$, (D) Shaghayegh JAVANMARD4 \\ 1'sfahan University of Medical Sciences, School of Pharmacy and Pharmaceutical Sciences, Department of Pharmacology and Toxicology, Isfahan \\ Pharmaceutical Sciences Research Center, Isfahan, Iran \\ 2Isfahan University of Medical Sciences, School of Pharmacy and Pharmaceutical Sciences, Department of Pharmacognosy, Isfahan, Iran \\ 3Isfahan University of Medical Sciences, Vice Chancellery for Food and Drugs, Office for Drug, Food, Cosmetics and hygienic Product's QC Laboratory, \\ Isfahan, Iran \\ ${ }^{4}$ Isfahan University of Medical Sciences, Cardiovascular Research Institute, Applied Physiology Research Center, Isfahan, Iran
}

\section{ABSTRACT}

Objectives: Oxidative stress plays a major role in endothelial dysfunction. Citral is a monoterpene aldehyde with antioxidant properties. This study aimed to investigate the effect of citral on human umbilical vein endothelial cells (HUVECs) under hydrogen peroxide $\left(\mathrm{H}_{2} \mathrm{O}_{2}\right)$-induced oxidative stress.

Materials and Methods: The cells were treated with citral $(0.625-10 \mu \mathrm{g} / \mathrm{mL})$ for $24 \mathrm{~h}$ before exposure to $\mathrm{H}_{2} \mathrm{O}_{2}(0.5 \mathrm{mM}, 2 \mathrm{~h})$. Cell viability was evaluated by 3-(4,5-dimethylthiazol-2-yl)-2,5-diphenyl-tetrazolium bromide (MTT) assay. The hydroperoxide concentrations and ferric reducing ability of plasma (FRAP) were measured in intra- and extracellular fluids.

Results: Pretreatment of HUVECs with citral at concentrations of 5 and $10 \mu \mathrm{g} / \mathrm{mL}$ significantly enhanced the cell viability in $\mathrm{H}_{2} \mathrm{O}_{2}$-induced cytotoxicity. It reduced intracellular hydroperoxide levels at the concentrations of 5 and $10 \mu \mathrm{g} / \mathrm{mL}$ and extracellular hydroperoxide levels at the concentrations of $2.5-10 \mu \mathrm{g} / \mathrm{mL}$. Pretreatment with citral significantly increased the FRAP value in intra- and extracellular fluids at the concentration range of $1.25-10$ $\mu \mathrm{g} / \mathrm{mL}$.

Conclusion: Antioxidant and cytoprotective effects were found for citral against oxidative damage induced by $\mathrm{H}_{2} \mathrm{O}_{2}$ in human endothelial cells. However, more studies in this area are needed to assess its clinical value for prevention and treatment of cardiovascular diseases.

Key words: Citral, HUVECs, oxidative stress, antioxidant, hydrogen peroxide

\section{ÖZ}

Amaç: Oksidatif stres endotel disfonksiyonda önemli bir rol oynamaktadır. Sitral, antioksidan özelliklere sahip olan monoterpen bir aldehittir. Bu çalışma, sitralin, hidrojen peroksit $\left(\mathrm{H}_{2} \mathrm{O}_{2}\right)$ kaynaklı oksidatif stres altındaki insan göbek kordonu ven endotel hücreleri (HUVEC) üzerindeki etkisini araștırmak amacı ile gerçekleștirilmiştir.

Gereç ve Yöntemler: Hücreler, $\mathrm{H}_{2} \mathrm{O}_{2}{ }^{\prime}$ ye $(0,5 \mathrm{mM}, 2$ saat) maruz kalmadan önce 24 saat boyunca sitral $(0,625-10 \mu \mathrm{g} / \mathrm{mL})$ ile muamele edildi. Hücre canlılı̆̆ı, 3-(4, 5-dimetiltiazol-2-yl)-2, 5-difenil-tetrazolyum bromür deneyi ile belirlendi. Hidroperoksit yoğunluğu ve plazmadaki ferrik demir iyonu indirgeme kapasitesi (FRAP) hücre içi ve dışı sıvılarda ölçüldü.

Bulgular: HUVEC'lerin önceden sitral ile 5 ve $10 \mu \mathrm{g} / \mathrm{mL}$ yoğunluğunda maruz kalması, $\mathrm{H}_{2} \mathrm{O}_{2}$ kaynaklı sitotoksisitede hücre canlılığını önemli ölçüde artırdı. Bu hücre içi hidroperoksit seviyesini 5 ve $10 \mu \mathrm{g} / \mathrm{mL}$ yoğunluğuna ve hücre dışı hidroperoksit seviyesini ise 2,5-10 $\mu \mathrm{g} / \mathrm{mL}$ yoğunluğuna düşürdü. Sitrale önceden maruz kalmaları, 1,25-10 $\mu \mathrm{g} / \mathrm{mL}$ yoğunluk aralığında hücre içi ve hücre dışı sıvılarda FRAP değerini önemli ölçüde artırdı. Sonuç: İnsan endotel hücrelerinde $\mathrm{H}_{2} \mathrm{O}_{2}$ 'nin neden olduğu oksidatif hasara karşı sitralin antioksidan ve sitoprotektif etkili olduğu bulundu. Ancak, kardiyovasküler hastalıkların önlenmesi ve tedavisinde klinik değeri ve yerini tespit edebilmek için bu alanda daha fazla çalışma ve deneye intiyaç vardır.

Anahtar kelimeler: Sitral, HUVEC'ler, oksidatif hasar, antioksidan, hidrojen peroksit

*Correspondence: E-mail: leila_safaeian@pharm.mui.ac.ir, Phone: +98 3137927087 ORCID-ID: orcid.org/0000-0002-7811-3406

Received: 24.12.2018, Accepted: 14.02.2019

-Turk J Pharm Sci, Published by Galenos Publishing House. 


\section{INTRODUCTION}

Cardiovascular diseases (CVDs) are the most prominent causes of death worldwide.' Many studies have confirmed the pivotal role of oxidative stress in the pathogenesis and progression of CVDs. Oxidative stress is a state of overproduction of free radicals and an imbalance between oxidants and antioxidants. Cellular damage and endothelial dysfunction resulting from excessive generation of reactive oxygen species (ROS) have been reported to be involved in various CVDs. ${ }^{2}$ Superoxide anion, hydroxyl radicals, lipid radicals, and hydrogen peroxide $\left(\mathrm{H}_{2} \mathrm{O}_{2}\right)$ are examples of ROS in the vascular system. ROS have a physiological role in controlling cardiovascular homeostasis by mediating diverse biological responses such as induction of host defense genes, activation of transcription factors, phosphorylation of kinases, and mobilization of ion transport systems. ${ }^{3,4}$ Besides their physiological role, ROS also play an important pathophysiological role in inflammation, hypertrophy, proliferation, apoptosis, migration, fibrosis, angiogenesis, vascular remodeling, and endothelial dysfunction. 5,6

Natural antioxidants are widely distributed in fruits, vegetables, and medicinal plants, produced via the secondary metabolisms and possessing various biological activities. ${ }^{7.8}$ In many investigations, herbal antioxidants and bioactive plant constituents have been associated with beneficial therapeutic effects and a reduction in the risk of CVDs. ${ }^{9}$

Citral (3,7-dimethyl-2,6-octadienal) is one of the most important natural flavoring compounds, widely used in the food, pharmaceutical, and cosmetic industries. ${ }^{10}$ This monoterpene aldehyde also called lemonal and is a mixture of geranial (transcitral or citral A) and neral (cis-citral or citral B)." Citral is present in several plants with lemon aroma such as lemongrass (Cymbopogon citratus) and lemon balm (Melissa officinalis).12,13 This essential oil has exhibited antifungal, bactericidal, insecticidal, anticancer, analgesic, anti-inflammatory, anticonvulsant, and spasmolytic activities in pharmacological studies.10,14 Moreover, some beneficial cardiovascular effects have been reported for citral due to its antioxidant, radical scavenging, anti-inflammatory, and vasodilatory properties. ${ }^{15,16}$ The present study aimed to investigate the possible protective effects of citral against oxidative damage induced by $\mathrm{H}_{2} \mathrm{O}_{2}$ in human umbilical vein endothelial cells (HUVECs).

\section{MATERIALS AND METHODS}

\section{Cell culture}

HUVECs were maintained in Dulbecco's Modified Eagle's Medium in a humidified atmosphere of $5 \% \mathrm{CO}_{2}$ at $37{ }^{\circ} \mathrm{C}$. The medium was supplemented with $10 \%$ fetal bovine serum, 100 $\mu / \mathrm{mL}$ penicillin, and $100 \mu \mathrm{g} / \mathrm{mL}$ streptomycin. Citral (Sigma, Germany) was dissolved in dimethyl sulfoxide $0.8 \%$ and diluted with cell culture medium to get different concentrations as required.

\section{Cell viability assay}

The viability of HUVECs was determined by 3-(4,5-dimethylthiazol-2-yl)-2,5-diphenyl- tetrazolium bromide
(MTT) assay (Bioidea Co., Tehran, Iran) for evaluation of the potential cytotoxicity of citral under normal conditions and its possible cytoprotective effect against oxidative stress. ${ }^{17}$ In brief, the cell monolayer in exponential growth was harvested and $1.5 \times 10^{5}$ cells $/ \mathrm{mL}$ were seeded in each well of the 96 -well plates. Twenty-four hours after plating, the HUVECs were treated with 0.625 to $100 \mu \mathrm{g} / \mathrm{mL}$ citral and incubated for an additional $24 \mathrm{~h}$ for assessment of the effect of citral on HUVEC proliferation under normal conditions. After washing out with butylene succinate (PBS), MTT reagent was added to each well, followed by further incubation for $3 \mathrm{~h}$. Then dimethyl sulfoxide was used and the absorbance was measured at $570 \mathrm{~nm}$ by a microplate reader.

For evaluation of the cytoprotective effect of citral on HUVECs against $\mathrm{H}_{2} \mathrm{O}_{2}$-induced oxidative stress, the cells were preincubated with 0.625 to $10 \mu \mathrm{g} / \mathrm{mL}$ citral for $24 \mathrm{~h}$ and then the citral was removed from the media and the wells were washed out with PBS. After that the cells were exposed to $0.5 \mathrm{mM}$ $\mathrm{H}_{2} \mathrm{O}_{2}$ for $2 \mathrm{~h}$. The rest of the experiment was performed as above. The cells without any exposure to the extract or $\mathrm{H}_{2} \mathrm{O}_{2}$ were considered the negative control. The viability of treated samples was measured according to the following formula and each experiment was tested in triplicate:

Cell viability $(\%)=(O D$ test $-O D$ blank $/ O D$ negative control $-O D$ blank) $\times 100$

\section{Hydroperoxide assay}

A ferrous ion oxidation by xylenol orange (FOX-1) kit (Hakiman Shargh Research Co., Isfahan, Iran) was used for evaluation of the effects of pretreatment with citral on intra- and extracellular hydroperoxide levels. In this method, hydroperoxides are detected based upon oxidation of reagent $\mathrm{Fe}^{+2}$ to $\mathrm{Fe}^{+3}$ by oxidizing agents and formation of a color complex through its binding to xylenol orange in an aqueous medium containing sorbitol. ${ }^{18}$ Ten milliliters of supernatant of the cells or the cell lysates after being pretreated with different concentrations of citral and then exposed to $\mathrm{H}_{2} \mathrm{O}_{2}$ was mixed with $190 \mu \mathrm{L}$ of FOX-1 reagent. After incubation for $30 \mathrm{~min}$ at $40{ }^{\circ} \mathrm{C}$, the absorbance was measured at $540 \mathrm{~nm}$ using a microplate reader/spectrophotometer. The hydroperoxide content of the samples was estimated as $\mathrm{H}_{2} \mathrm{O}_{2}$ equivalents using a $\mathrm{H}_{2} \mathrm{O}_{2}$ standard curve.

\section{Ferric reducing ability of plasma assay (FRAP)}

The effects of citral on the intra- and extracellular FRAP was determined by a commercial kit (Hakiman Shargh Research Co., Isfahan, Iran).19 In this assay, the total antioxidant capacity is estimated based on the reduction of ferric-tripyridyltriazine complex to ferrous form. Briefly, after pretreatment of HUVECs with different concentrations of citral and then exposure to $\mathrm{H}_{2} \mathrm{O}_{2}, 10 \mu \mathrm{L}$ of the supernatant of the cells or the cell lysates was added to $200 \mu \mathrm{L}$ of FRAP reagent containing tripyridyltriazine/ ferric chloride/acetate buffer. The reaction mixture was incubated for $40 \mathrm{~min}$ at $40{ }^{\circ} \mathrm{C}$ and absorbance was read at 570 $\mathrm{nm}$ using a microplate reader/spectrophotometer. The FRAP values of the samples were calculated using a standard curve of $\mathrm{FeSO}_{4} \times 7 \mathrm{H}_{2} \mathrm{O}$ concentrations and were expressed as Fell equivalents. 


\section{Statistical analysis}

The data were presented as mean \pm standard error of the mean. For statistical analysis, One-Way ANOVA followed by Tukey's post-hoc test was performed using SPSS version 18.0. A p value $<0.05$ was considered significant.

\section{RESULTS}

\section{Effect of citral on HUVEC viability}

The potential cytotoxicity of citral on HUVECs was evaluated by MTT assay. There was an inhibitory effect on HUVEC proliferation after $24 \mathrm{~h}$ exposure to the concentrations of 20$100 \mu \mathrm{g} / \mathrm{mL}$ of citral ( $p<0.001$ compared with control cells) (Figure 1). Therefore, citral was used at the concentration range of $0.625-10 \mu \mathrm{g} / \mathrm{mL}$ for further studies.

\section{Effect of citral on $\mathrm{H}_{2} \mathrm{O}_{2}$-induced oxidative stress}

Figure 2 shows the cytoprotective effect of citral against oxidative cell death induced by $\mathrm{H}_{2} \mathrm{O}_{2}$ using an MTT assay. $\mathrm{H}_{2} \mathrm{O}_{2}$ $(0.5 \mathrm{mM})$ produced a significant reduction in HUVEC viability compared with the control cells $(p<0.001)$. Pretreatment with citral at the concentrations of 5 and $10 \mu \mathrm{g} / \mathrm{mL}$ significantly enhanced cell viability in $\mathrm{H}_{2} \mathrm{O}_{2}$-induced cytotoxicity $(p=0.005$ and $p<0.001$, respectively).

\section{Effects of citral on hydroperoxide levels}

The FOX-1 assay was performed to detect the effects of citral on intra- and extracellular hydroperoxide concentrations in HUVECs after exposure to the oxidative stress induced by $\mathrm{H}_{2} \mathrm{O}_{2}$. A significant increase in hydroperoxide production was observed in the presence of $0.5 \mathrm{mM} \mathrm{H}_{2} \mathrm{O}_{2}$ as compared to the untreated normal control ( $p<0.001$ ). Incubation of HUVECs with citral significantly decreased the intracellular hydroperoxide levels at the concentrations of $5 \mu \mathrm{g} / \mathrm{mL}(p=0.35)$ and $10 \mu \mathrm{g} /$ $\mathrm{mL}(p=0.001)$ compared to the cells treated with $\mathrm{H}_{2} \mathrm{O}_{2}$ alone (Figure 3A). Citral also caused a significant reduction in the extracellular hydroperoxide levels at the concentrations of 2.5, 5 , and $10 \mu \mathrm{g} / \mathrm{mL}(\mathrm{p}=0.003, p<0.001$, and $p<0.001$, respectively) (Figure 3B).

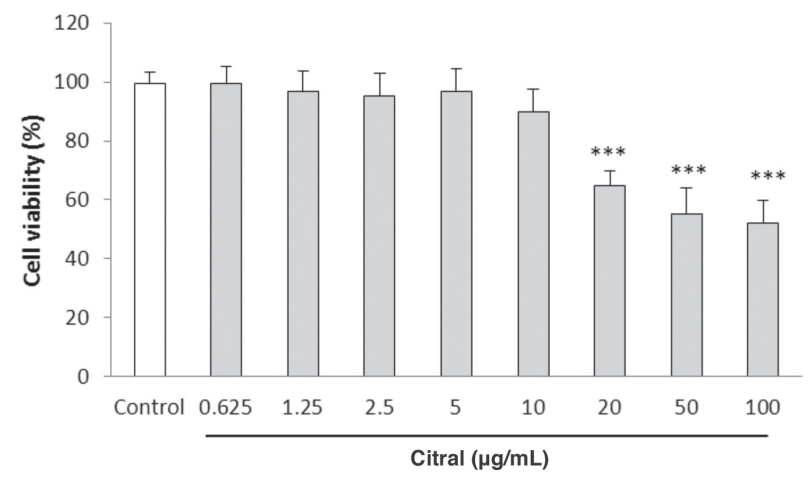

Figure 1. Effect of citral on HUVEC viability determined by MTT assay. Cells were incubated with different concentrations of citral $(0.625-100 \mu \mathrm{g} / \mathrm{mL})$ for $24 \mathrm{~h}$. Values are means \pm SEM from three independent experiments in triplicate. ${ }^{* * *} p<0.001$ versus control (untreated cells)

HUVEC: Human umbilical vein endothelial cell, MTT: 3-(4,5-dimethylthiazol-2-yl)-2,5diphenyl-tetrazolium bromide, SEM: Standard error of the mean

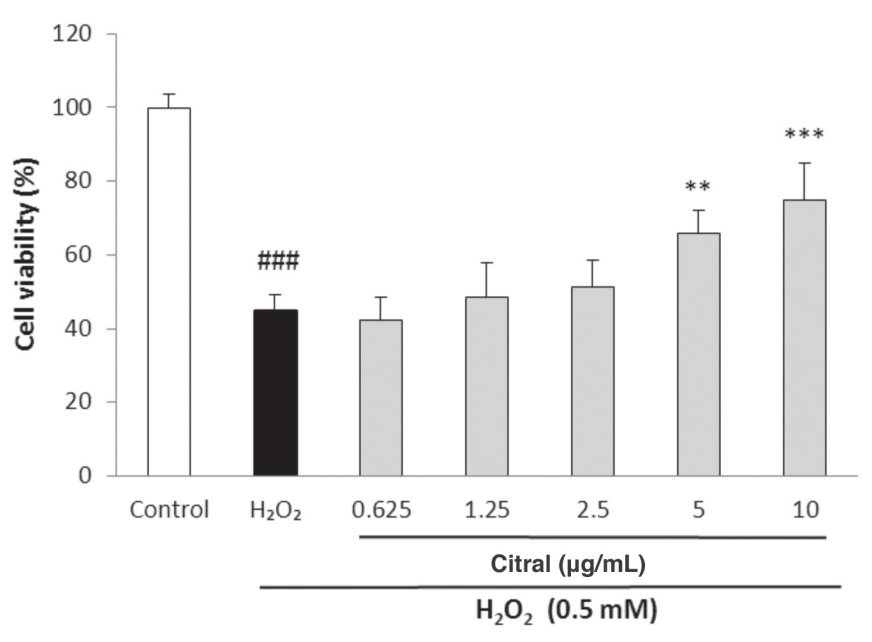

Figure 2. Effect of citral on HUVEC viability in $\mathrm{H}_{2} \mathrm{O}_{2}$-induced oxidative stress determined by MTT assay. Cells were incubated with $\mathrm{H}_{2} \mathrm{O}_{2}(0.5$ $\mathrm{mM}, 2 \mathrm{~h}$ ) after pretreatment with different concentrations of citral (0.625$10 \mu \mathrm{g} / \mathrm{mL}$ ). Values are means \pm SEM from three independent experiments in triplicate. \#\#\#p<0.001 versus control (untreated cells), ${ }^{* *} p<0.01$ and ${ }^{* * *}$ p $<0.001$ versus $\mathrm{H}_{2} \mathrm{O}_{2}$ stimulated cells

HUVEC: Human umbilical vein endothelial cell, MTT: 3-(4,5-dimethylthiazol-2-yl)-2,5diphenyl-tetrazolium bromide, SEM: Standard error of the mean
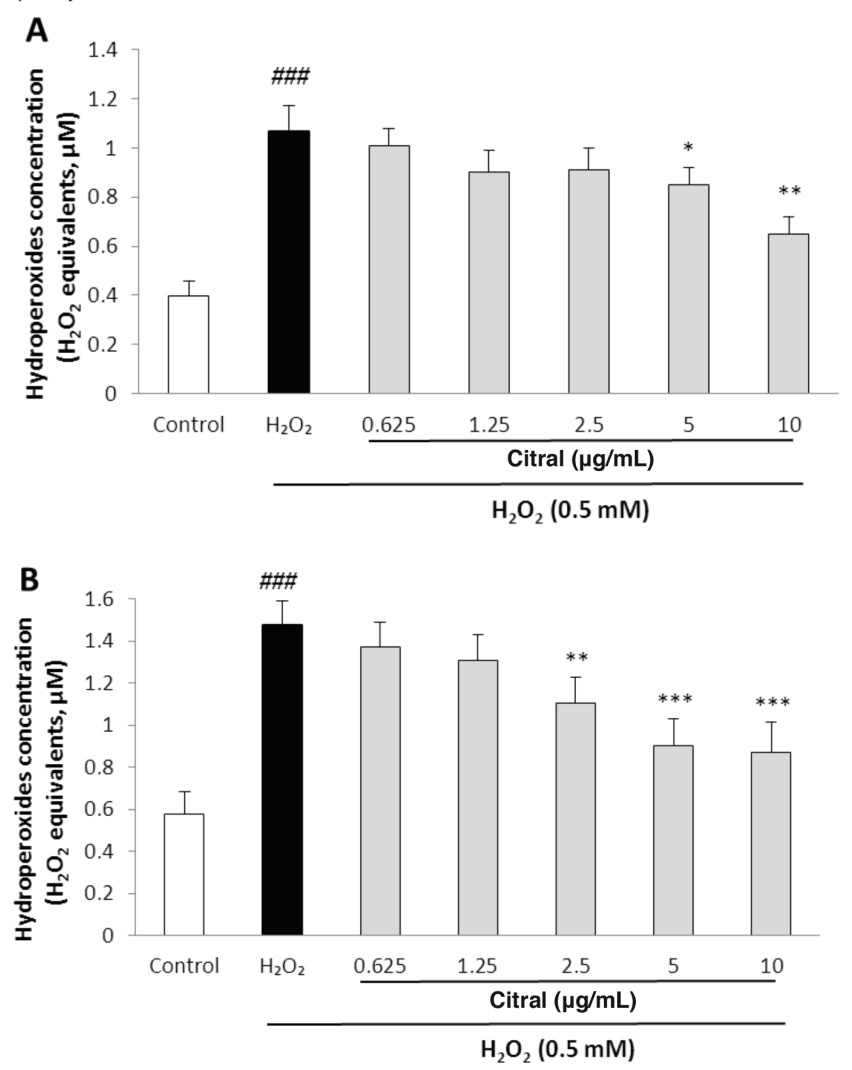

Figure 3. Effect of citral on intra- A) and extracellular $B$ ) hydroperoxide concentration in $\mathrm{HUVECs}$ as $\mathrm{H}_{2} \mathrm{O}_{2}$ equivalents determined by FOX-1 method. Cells were incubated with $\mathrm{H} 2 \mathrm{O} 2(0.5 \mathrm{mM}, 2 \mathrm{~h})$ after pretreatment with different concentrations of citral $(0.625-10 \mu \mathrm{g} / \mathrm{mL})$. Values are means \pm SEM from three independent experiments in triplicate. \#\#\#p<0.001 versus control (untreated cells), ${ }^{*} p<0.05$, ${ }^{* *} p<0.01$, and ${ }^{* * *} p<0.001$ versus $\mathrm{H}_{2} \mathrm{O}_{2}$ stimulated cells

HUVEC: Human umbilical vein endothelial cell, FOX-1: Ferrous ion oxidation by xylenol orange, SEM: Standard error of the mean 


\section{Effects of citral on FRAP value}

The effect of citral on total antioxidant capacity was evaluated by FRAP assay. Exposure of HUVECs to $\mathrm{H}_{2} \mathrm{O}_{2}$ resulted in a significant decrease in the FRAP value $(p=0.007)$. Pretreatment with citral significantly increased the FRAP value in intracellular fluids at the concentrations of $1.25,2.5,5$, and $10 \mu \mathrm{g} / \mathrm{mL}$ $(p=0.025, p=0.004, p=0.002$, and $p=0.003$, respectively) (Figure $4 A$ ). It also improved the FRAP value in extracellular fluids at the concentrations of $1.25,2.5,5$, and $10 \mu \mathrm{g} / \mathrm{mL}(\mathrm{p}=0.016$, $p=0.001, p<0.001$, and $p<0.001$, respectively) (Figure 4B).
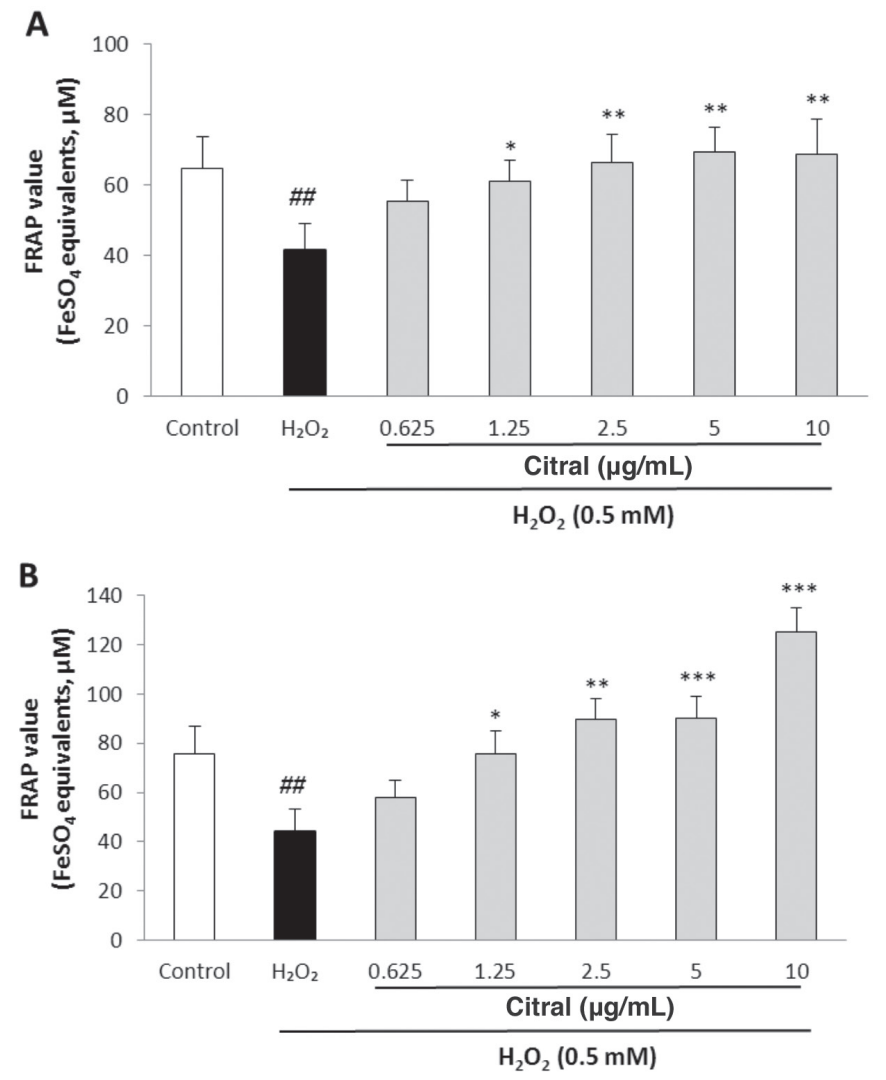

Figure 4. Effect of citral on intra- A) and extracellular B) FRAP value in HUVECs determined as ferrous sulfate equivalents. Cells were incubated with $\mathrm{H} 2 \mathrm{O} 2(0.5 \mathrm{mM}, 2 \mathrm{~h})$ after pretreatment with different concentrations of citral $(0.625-10 \mu \mathrm{g} / \mathrm{mL})$. Values are means \pm SEM from three independent experiments in triplicate. \#\#p<0.01 versus control (untreated cells), ${ }^{*} p<0.05,{ }^{* *} p<0.01$, and ${ }^{* * *} p<0.001$ versus $\mathrm{H} 2 \mathrm{O} 2$ stimulated cells

FRAP: Ferric reducing ability of plasma, HUVECs: Human umbilical vein endothelial cells

\section{DISCUSSION}

The findings of the present study showed cytoprotective and antioxidant effects of citral against oxidative stress induced by $\mathrm{H}_{2} \mathrm{O}_{2}$ in HUVECs. Citral protected the cells against oxidative cell death at the concentrations of 5 and $10 \mu \mathrm{g} / \mathrm{mL}$. It reduced hydroperoxide levels and increased the FRAP value in both intra- and extracellular fluid at different concentration ranges.

$\mathrm{H}_{2} \mathrm{O}_{2}$ is a stable ROS with capability of readily diffusing through the cellular membrane and plays a significant role in vascular cell signaling such as proliferation, apoptosis, and inflammation. ${ }^{20} \mathrm{H}_{2} \mathrm{O}_{2}$ as a trigger of oxidative stress in human endothelial cells has been used in many studies to provide insight into the mechanisms of CVD development. In the present study, the exposure of HUVECs to $\mathrm{H}_{2} \mathrm{O}_{2}$ caused significant reductions in cell viability and the FRAP value and an increase in hydroperoxide levels.

Citral, the major constituent of the essential oil of lemon-scented plants, has been reported to possess several pharmacological activities." Studies have shown that citral dose- and timedependently protects some normal cells against distressing stimuli. At higher concentrations, it may show a cell growth inhibitory effect. ${ }^{21}$ Our results showed the cytoprotective activity of citral at concentrations less than $20 \mu \mathrm{g} / \mathrm{mL}$. Nordin et al. ${ }^{22}$ reported similar results for the effect of citral on the proliferation of normal spleen cells.

In the present investigation, citral also exhibited antioxidant effects through reducing hydroperoxides level and elevating the FRAP value in intra- and extracellular fluids. Measurement of ROS provides important data to study the effects of oxidative stress inducers and antioxidant remedies. FOX-1 is a sensitive assay for detection of hydroperoxides in biological samples. ${ }^{18}$ This assessment was performed to detect the effects of citral on intra- and extracellular hydroperoxide concentrations in HUVECs after exposure to oxidative stress induced by $\mathrm{H}_{2} \mathrm{O}_{2}$. The effect of citral on total antioxidant capacity was evaluated by FRAP assay. Antioxidants are enzymes or nonenzymatic compounds involved in the defense mechanisms against oxidative injuries induced by free radicals through preventing ROS creation and scavenging or eliminating ROS. ${ }^{23}$ FRAP is a simple and rapid colorimetric measurement widely used for screening of nonenzymatic antioxidants. ${ }^{19}$ Several studies have reported the antioxidant properties of the phytochemicals in citrus plants. ${ }^{24}$ Radical scavenging activity and induction of enzymatic and nonenzymatic cellular antioxidants have been presented for monoterpenes..$^{14}$ Cytoprotective and antioxidant effects have been described for Melissa officinalis extract as a plant containing a high level of citral against $\mathrm{H}_{2} \mathrm{O}_{2}$-induced oxidative stress in endothelial cells. ${ }^{25}$ Vimal et al. ${ }^{16}$ showed the in vitro antioxidant effects of some essential oil compounds including citral through evaluation of free radical scavenging, lipid peroxidation, and antioxidant enzymes activities. Bouzenna et al. ${ }^{26}$ reported a protective effect of citral against aspirininduced oxidative stress through attenuation of mitogenactivated protein kinases, reduction of malondialdehyde level, and modulation of superoxide dismutase and glutathione activities. Protection against high glucose-induced oxidative stress has also been found for citral through inhibiting the ROS activated protein kinases signaling pathway in HepG2 cells. ${ }^{27}$

Besides antioxidant properties, some studies have revealed anti-inflammatory effects of citral by suppression of proinflammatory cytokines such as tumor necrosis factor- $\alpha$ and interleukins (IL-6 and IL-8), inhibition of inducible endothelial nitric oxide synthase transcription, reduction of p50 nuclear factor- $\kappa B$ levels, and suppression of vascular cell adhesion molecule 1 , intercellular adhesion molecule 1 , and cyclooxygenase-2 expression. ${ }^{28-31}$ 
Moreover, the helpful vascular effects including vasodilatory effect likely through affecting the intracellular calcium concentration and nitric oxide pathway have been found for citral in isolated aorta. ${ }^{15}$ Regarding the beneficial cardiovascular activities such as antioxidant, cytoprotective, anti-inflammatory, and vasorelaxant effects, citral as a natural component could be suggested for prevention of vascular oxidative stress and endothelial dysfunction and consequently prevention of CVDs.

\section{CONCLUSION}

Citral was found to protect HUVECs against oxidative damage induced by $\mathrm{H}_{2} \mathrm{O}_{2}$ by enhancing total antioxidant capacity and reducing hydroperoxide production. However, more studies in this area are required to evaluate its clinical value for prevention and treatment of CVDs.

\section{ACKNOWLEDGMENTS}

This study was financially supported by the Vice-Chancellery for Research and Technology of Isfahan University of Medical Sciences (research projects no. 393659).

Conflicts of interest: No conflict of interest was declared by the authors. The authors alone are responsible for the content and writing of the paper.

\section{REFERENCES}

1. Mendis S, Puska P, Norrving B. Global atlas on cardiovascular disease prevention and control. Geneva: WHO, World Heart Federation, World Stroke Organization. 2011:155.

2. Cervantes Gracia K, Llanas-Cornejo D, Husi H. CVD and oxidative stress. J Clin Med. 2017;6:22.

3. Droge W. Free radicals in the physiological control of cell function. Physiol Rev. 2002;82:47-95.

4. Fujino G, Noguchi T, Matsuzawa A, Yamauchi S, Saitoh M, Takeda K, Ichijo $\mathrm{H}$. Thioredoxin and TRAF family proteins regulate reactive oxygen species-dependent activation of ASK1 through reciprocal modulation of the N-terminal homophilic interaction of ASK1. Mol Cell Biol. 2007;27:8152-8163.

5. Touyz RM, Briones AM. Reactive oxygen species and vascular biology: implications in human hypertension. Hypertens Res. 2011;34:5.

6. Schulz E, Anter E, Keaney J, John F. Oxidative stress, antioxidants, and endothelial function. Curr Med Chem. 2004;11:1093-1104.

7. Yegdaneh A, Ghannadi A, Dayani L. Chemical constituents and biological activities of two Iranian Cystoseira species. Res Pharm Sci. 2016;11:311317.

8. Mesripour A, Moghimi F, Rafieian-Kopaie M. The effect of Cinnamomum zeylanicum bark water extract on memory performance in alloxaninduced diabetic mice. Res Pharm Sci. 2016;11:318-323.

9. Kris-Etherton PM, Keen CL. Evidence that the antioxidant flavonoids in tea and cocoa are beneficial for cardiovascular health. Curr Opin Lipidol. 2002;13:41-49.

10. Lu WC, Huang DW, Wang CC, Yeh CH, Tsai JC, Huang YT, Li P-H. Preparation, characterization, and antimicrobial activity of nanoemulsions incorporating citral essential oil. J Food Drug Anal. 2018;26:82-89.
11. Devi RC, Sim SM, Ismail R. Spasmolytic effect of citral and extracts of Cymbopogon citratus on isolated rabbit ileum. J Smooth Muscle Res. 2011;47:143-156.

12. Wilson ND, Ivanova MS, Watt RA, Moffat AC. The quantification of citral in lemongrass and lemon oils by near-infrared spectroscopy. J Pharm Pharmacol. 2002;54:1257-1263.

13. Sadraei H, Ghannadi A, Malekshahi K. Relaxant effect of essential oil of Melissa officinalis and citral on rat ileum contractions. Fitoterapia. 2003;74:445-452.

14. Porto MdeP, da Silva GN, Luperini BC, Bachiega TF, de Castro Marcondes JP, Sforcin JM, Salvadori DMF. Citral and eugenol modulate DNA damage and pro-inflammatory mediator genes in murine peritoneal macrophages. Mol Biol Rep. 2014;41:7043-7051.

15. da Silva R, de Morais L, Silva A, Bastos CMS, Pereira-Gonçalves Á, Kerntopf MR, Menezes IRA, Leal-Cardoso JH, Barbosa R. Vasorelaxant effect of the Lippia alba essential oil and its major constituent, citral, on the contractility of isolated rat aorta. Biomed Pharmacother. 2018;108:792-798.

16. Vimal M, Vijaya P, Mumtaz P, Farhath M. Free radical scavenging activity of essential oil compounds citral, limonene, menthone and thymol by using different methods. J Pharm Res. 2013;6:410.

17. Ma ZC, Hong Q, Wang YG, Tan HL, Xiao CR, Liang QD, Wang D-G, Gao $Y$. Ferulic acid protects lymphocytes from radiation-predisposed oxidative stress through extracellular regulated kinase. Int J Radiat Biol. 2011;87:130-140.

18. Wolf SP. Ferrous ion oxidation in presence of ferric ion indicator xylenol orange for measurement of hydroperoxides. Methods Enzymol. 1994;233:182-189.

19. Benzie IF, Strain JJ. The ferric reducing ability of plasma (FRAP) as a measure of "antioxidant power": the FRAP assay. Anal Biochem. 1996;239:70-76.

20. Cai H. Hydrogen peroxide regulation of endothelial function: origins, mechanisms, and consequences. Cardiovasc Res. 2005;68:26-36.

21. Patel PB, Thakkar VR. Addition of citral controls ROS and reduces toxicity in 5-fluorouracil treated Schizosaccharomyces pombe cells. Indian J Exp Biol. 2015;53:152-157.

22. Nordin N, Yeap SK, Zamberi NR, Abu N, Mohamad NE, Rahman HS, How CW, Masarudin MJ, Abdullah R, Alitheen NB. Characterization and toxicity of citral incorporated with nanostructured lipid carrier. PeerJ. 2018;6:e3916.

23. Pellegrini N, Serafini M, Colombi B, Del Rio D, Salvatore S, Bianchi M, Brighenti F. Total antioxidant capacity of plant foods, beverages and oils consumed in Italy assessed by three different in vitro assays. J Nutr. 2003;133:2812-2819.

24. Zou Z, Xi W, Hu Y, Nie C, Zhou Z. Antioxidant activity of Citrus fruits. Food Chem. 2016;196:885-896.

25. Safaeian L, Sajjadi SE, Javanmard SH, Montazeri H, Samani F. Protective effect of Melissa officinalis extract against $\mathrm{H}_{2} \mathrm{O}_{2}$-induced oxidative stress in human vascular endothelial cells. Res Pharm Sci. 2016;11:383-389.

26. Bouzenna H, Hfaiedh N, Giroux-Metges MA, Elfeki A, Talarmin H. Biological properties of citral and its potential protective effects against cytotoxicity caused by aspirin in the IEC-6 cells. Biomed Pharmacother. 2017;87:653-660.

27. Subramaniyan SD, Kumar AN. Citral, A monoterpene protect against high glucose induced oxidative injury in HepG2 cell in vitro-an experimental study. J Clin Diagn Res. 2017;11:BC10-BC15. 
28. Sforcin J, Amaral J, Fernandes Jr A, Sousa J, Bastos J. Lemongrass effects on IL-1 $\beta$ and IL-6 production by macrophages. Nat Prod Res. 2009;23:1151-1159.

29. Lin CT, Chen CJ, Lin TY, Tung JC, Wang SY. Anti-inflammation activity of fruit essential oil from Cinnamomum insularimontanum Hayata. Bioresour Technol. 2008;99:8783-8787.
30. Katsukawa M, Nakata R, Takizawa Y, Hori K, Takahashi S, Inoue H. Citral, a component of lemongrass oil, activates PPAR $\alpha$ and $\gamma$ and suppresses COX-2 expression. Biochim Biophys Acta Mol Cell Biol Lipids. 2010;1801:1214-1220.

31. Song $Y$, Zhao H, Liu J, Fang C, Miao R. Effects of citral on lipopolysaccharide-induced inflammation in human umbilical vein endothelial cells. Inflammation. 2016;39:663-671. 